\title{
Error Analysis of Subject-Verb Agreement Made by Students in Meurandeh Langsa
}

\author{
Rasyid Gunawan ${ }^{1}$, Reni Lestari ${ }^{2}$, Putri Mulyani ${ }^{3}$ \\ ${ }^{1,2,3}$ English Department, Samudra University, \\ Langsa, Aceh, Indonesia \\ e-mail: Renyjestari011@gmail.com
}

Received: 25 July 2018

Accepted: 27 November 2018

\begin{abstract}
This research aimed at identifying the subject-verb agreement errors in students' writing. This research applied a descriptive research. The data were collected through test and non-test instruments. Test instruments were conducted through writing test and non-test instruments were through questionnaire and interview. The data obtained from both test and non-test instruments were conducted by employing descriptive analysis. This research analyzed students' narrative writing based on Surface Strategy Taxonomy proposed by Dulay, Burt and Krashen (1982). This result revealed the types of error in subject-verb agreement in the students' narrative writing covering omission, addition and misinformation. In conclusion, the students involved in the research made a number of errors. It was found that the students' ability to use subject-verb agreement in English was still low.
\end{abstract}

Keywords: narrative writing, agreement, omission, addition, misinformation.

\section{Introduction}

Language skill consists of four aspects: listening, speaking, reading and writing. The last skill (writing) comes at the end of one's mastery over the other three skills. Writing is not an inborn skill. It must be learned and practiced in a formal instructional setting. This skill needs the learner to generate ideas and transfer them into text. The gravity of difficulty goes up, because a learner has to consider the grammar, writing convention of the target language and the like of the target language systems. Thus, grammar is a significant aspect of language that a learner has to develop and master among all other aspects of language. Grammar is a set of language rules governing the sounds, words, sentences, and other elements. In a restricted sense, grammar refers only to the study sentence and word structure (syntax and morphology), excluding lexical and pronunciation. The grammar of English, which is a foreign language for most Indonesians, deserves more focused attention. It can be assumed that Indonesian learners of English must have difficulties in learning English grammar. They must have committed errors in the way of developing competence in EFL.

Students of higher education are expected to be able to use English to write sentences, paragraphs, or even essays well. The sentences written by the students are expected to be not only grammatically correct but also semantically acceptable. Grammatically correct sentence means that the sentence should follow the rules of the language. Meanwhile, semantically acceptable sentence means that the sentence should be meaningful and far 
from ambiguity. This requirement is in accordance with their level of education. They are required to do so because as university students, they are exposed with so many academic works to complete.

This research was on subject verb agreement. The Researchers made questionnaires and descriptive paragraph related to subject verb agreement. To this matter, questions were formulated as follow:

a. What kinds of subject-verb agreement errors were mostly made by the students in writing paragraph?

b. What types of error did they make in their descriptive writings concerning the subject verb agreement?

\section{Literature Review}

\subsection{Error}

Error is the systematic deviations done by learners who have not mastered the rules of the target language. It happens repeatedly as an unconscious process. Errors are systematic and predictable (Ellis, 1995: 26). Errors reflect a lack of underlying competence in the language they learn. Unlike error, mistake is related to language performance. The learners have known the correct rules, but they are unable to perform their competence. Mistakes can be caused by slip of the tongue and physical condition, such as fatigue, lack of attention, and strong emotion. An example of a mistake is the slip of the tongue done by someone when he wants to say mood but he wrongly utters the word moon.

However, errors are the part of natural process in learning a language (Harmer, 2007) and play a crucial role for the learners to uncover the rules of target language by the feedback they get on the errors (Ellis and Barkuizen, 2005).

\subsection{Subject Verb Agreement}

Every sentence needs agreement grammar. According to Mas'ud, agreement grammar is very important to be learnt if someone wants to understand and use English in written and spoken well (Mas'ud, 1996). It means that agreement grammar is needed in written and spoken English. Agreement grammar will help the reader or listener to understand the clear meaning of sentences.

According to Mas'ud (1996), agreement (concord) is agreement between the subjects with its verb (predicate). Similarly, Leech (2006) states that concord is a relation between two elements such that they match one another in terms of some grammatical feature. It means that agreement is a relation between two elements that should agree to each other, for instance the agreement between the subject and the verb used in a sentence.

From the explanations above, it is clear that subject-verb agreement is the agreement between subject and verb. If the subject is singular, the verb is also singular and if the subject is plural, the verb is plural, too because the meaning of a sentence will be ambiguous without the subject and the verb that agree to each other

\subsection{Subject Verb Agreement in Simple Present Tense}

According to Eastwood (1994), there is an agreement in present tense verb with the subject. Then, he adds that a third-person singular subject takes a verb with the suffix -s or es. It means that the verb in the simple present tense should agree to its subject. In verbal form, the subject is followed by a verb and do or does is used as the auxiliary for all subjects 
in the negative or question sentence. In the nominal form the subject is followed by an adjective, a noun or an adverb and instead of a verb it makes use of the copular verb to be.

\subsection{Subject Verb Agreement}

According to Eastwood (1994), there is agreement with be, have, and a present-simple verb. It means that subject-verb agreement of simple past tense is in nominal form.

\subsection{Subject Verb in Present Perfect Tense}

According to Eastwood (1994), there is agreement with be, have, and a present simple verb. It means that be and have are used in the present perfect tense for nominal and verbal form.

\section{Methodology}

In this research, descriptive research was conducted through analyzing errors of students' writing. The aim of this research is to describe the reality behind the phenomenon. The participants of this research were students in Langsa. In collecting the data, the researcher used three kinds of data collections: questionnaire, test, and interview. In this research, the main instrument was test. The researcher administered a test to the students to construct some paragraphs which were used as the data to be analyzed descriptively. Therefore, the researcher only constructed the instruction to do the test. Questionnaire was given to the participants in order to look for additional data that can support the data, which had been found through interview and document. It was needed because some students could not answer obviously in the interviews. It was written in form of multiple choices. Interview was conducted in conversations with a particular purpose. 10 participants were interviewed to know the condition of the participants. After doing data collection processes, the researcher analyzed the result of the interview and the document by using analytical descriptive method. In other words, the researcher described the data in sequence language through narrative form. The researcher identified students' errors from the result of the participants' answer sheets, especially whether the subjects agree to the verbs or not.

\section{Result and Discussion}

The results of the questionnaire were presented in the following tables

Table 1

The Student's Problem on English lesson

\begin{tabular}{|c|l|l|r|}
\hline NO. & STATEMENT & OPTIONS & FREQUENCY \\
\hline \multirow{3}{*}{1} & \multirow{2}{*}{$\begin{array}{l}\text { Apakah anda menyukai pelajaran bahasa } \\
\text { inggris? }\end{array}$} & Ya & 4 \\
\cline { 3 - 4 } & & Kurang Suka & 4 \\
\cline { 3 - 4 } & TOTAL & & 10 \\
\hline
\end{tabular}

Table 1 show that 6 students do not like subject verb agreement lesson and there are two students who like subject verb agreement lesson. Based on this information, the researcher concluded that most of the students had problems in studying English lesson. It 
Error Analysis of Subject-Verb Agreement Made by Students in Meurandeh Langsa, Rasyid Gunawan, Reni Lestari, Putri Mulyani

means that it is not surprising if they do not really master in using subject-verb agreement in constructing grammatically correct sentences.

Table 2

Students' Opinion about Subject-Verb Agreement

\begin{tabular}{|c|l|l|r|}
\hline NO. & STATEMENT & OPTIONS & FREQUENCY \\
\hline \multirow{3}{*}{1} & \multirow{2}{*}{$\begin{array}{c}\text { Apa anda mengetahui atau memahami } \\
\text { apa itu Subject-verb Agreement? }\end{array}$} & Paham & \\
\cline { 3 - 4 } & & Kurang Paham & 4 \\
\cline { 3 - 4 } & TOTAL & & 4 \\
\hline & Tidak Paham & 10 \\
\hline
\end{tabular}

Based on the data of students' opinion about subject-verb agreement, there are 4 students who understand SVG and six students did not know SVG From this information, the researcher concluded that most of the students thought that subject-verb agreement was difficult.

Table 3

The Student Problem on English lesson

\begin{tabular}{|l|l|l|r|}
\hline NO. & STATEMENT & OPTIONS & FREQUENCY \\
\hline 1 & $\begin{array}{l}\text { Apa ada kendala atau kesulitan saat } \\
\text { menentukan Subject verb Agreement? }\end{array}$ & Ya & 7 \\
\hline & & Tidak & 3 \\
\hline & TOTAL & & 10 \\
\hline
\end{tabular}

Here are the students' problems on subject-verb agreement; 7 students had problems and 3 students had no problems on subject-verb agreement. Based on this information, the researcher concluded that most students still got difficulty in using subject-verb agreement.

Table 4

Students' Opinion about Subject-Verb Agreement

\begin{tabular}{|c|l|l|r|}
\hline NO. & STATEMENT & OPTIONS & FREQUENCY \\
\hline \multirow{3}{*}{1} & \multirow{2}{*}{$\begin{array}{l}\text { Menurut anda penting atau tidak anda } \\
\text { mempelajari Subject Verb agreement? }\end{array}$} & Sangat Penting & 2 \\
\cline { 3 - 4 } & TOTAL & Penting & 7 \\
\cline { 3 - 4 } & & & 1 \\
\hline
\end{tabular}

Students' response on how important to learn subject-verb agreement was; 2 students assumed that it is very important, 7 students thought that it is important and 1 student said that it is not important. Based on this information, the researcher concluded that most of the students thought that learning subject-verb agreement is very important.

Table 5

Students' Opinion about Subject-Verb Agreement

\begin{tabular}{|l|l|l|r|}
\hline NO. & STATEMENT & OPTIONS & FREQUENCY \\
\hline 1 & $\begin{array}{l}\text { Solusi Seperti apa yang anda lakukan } \\
\text { ketika mendapatkan kesulitan dalam } \\
\text { menentukan Subject verb agreement? }\end{array}$ & Bertanya pada Guru & 4 \\
\hline
\end{tabular}




\begin{tabular}{|l|l|l|r|} 
& Bertanya pada Teman & 4 \\
\hline & & Belajar lagi & 2 \\
\hline & Total & & 10 \\
\hline
\end{tabular}

Table 5 indicates students' alternative if they faced difficulties in learning subject verb agreement; 4 students asked teachers; 4 students asked friends; 2 students learnt about subject verb agreement again. Based on this information, the researcher concluded that most of the students tried to ask their teachers and friends when they got difficulties in studying subject-verb agreement.

\subsection{The example of Student's Errors}

Error Analysis from Informant by Senior high school

The example of paragraph test:

The Informant must translate this paragraph into English.

\section{Kucing saya Meowy}

Saya bertemu paman saya di Bandung, satu bulan yang lalu, dia memberi saya seekor kucing. dia seekor kucing yang sangat imut, saya sangat senang pada waktu itu. karena diberi hadiah seekor kucing, saya berinamanya meowy, dia sangat lucu. rambutnya putih dan berkelahi, karena sering dibersihkan. Meowy suka sepotong ikan, daging atau mungkin seekor tikus. ketika saya kembali dari sekolah, dia selalu menungguku.

Table B-1: sri mulia

\begin{tabular}{|l|l|l|}
\hline No & \multicolumn{1}{|c|}{ Errors } & \multicolumn{1}{c|}{ Correct } \\
\hline 1 & I met *uncle & I met my uncle \\
\hline 2 & It often is wash clean & It is often washed clean \\
\hline 3 & Meowy like a piece of fish & Meowy likes fish \\
\hline & & \\
\hline
\end{tabular}

Table B-2: dio may asyra

\begin{tabular}{|l|l|l|}
\hline No & \multicolumn{1}{|c|}{ Errors } & \multicolumn{1}{c|}{ Correct } \\
\hline 1 & his gave me a cat & He gave me a cat \\
\hline 2 & He's a cute cat & It is a cute cat \\
\hline 3 & I am very happy & I was very happy \\
\hline 4 & I give me a name meowy & I gave the name meowy \\
\hline 5 & Because siring cleaned & it is often washed clean \\
\hline 6 & When I returned from school & I came back from school \\
\hline 7 & Two were always waiting for me & She always waited for me \\
\hline
\end{tabular}

Table B-3: mirna

\begin{tabular}{|l|l|l|}
\hline No & \multicolumn{1}{|c|}{ Errors } & \multicolumn{1}{c|}{ Correct } \\
\hline 1 & I am met my uncle to Bandung & I met my uncle in Bandung \\
\hline 2 & 1 month* & One month ago \\
\hline 3 & He is give* the cat & He gave me a cat \\
\hline 4 & It is * cute* & It is a cute cat \\
\hline 5 & Because give surprise *a cat & He gave me a cat as a gift \\
\hline 6 & $\begin{array}{l}\text { It is like to* fish, beef or maybe a } \\
\text { mouse }\end{array}$ & Meowy likes fish, meat or maybe mouse \\
\hline
\end{tabular}


Error Analysis of Subject-Verb Agreement Made by Students in Meurandeh Langsa, Rasyid Gunawan, Reni Lestari, Putri Mulyani

\begin{tabular}{|l|l}
\hline 7 & It is * waiting** \\
\hline
\end{tabular}

She always waited for me

Table B-4: pradhika pramudya

\begin{tabular}{|l|l|l|}
\hline No & \multicolumn{1}{|c|}{ Errors } & \multicolumn{1}{c|}{ Correct } \\
\hline 1 & I met *uncle in Bandung & I met my uncle in Bandung \\
\hline 2 & He give my a cat & He gave me a cat \\
\hline 3 & It is a cat cute & It is a cute cat \\
\hline 4 & I am very happy this time & I was very happy at that time \\
\hline 5 & *My *name meowy & I gave the name meowy \\
\hline 6 & It often is washed* & It is often washed clean \\
\hline
\end{tabular}

Table B-5: intan syafira

\begin{tabular}{|l|l|l|}
\hline No & \multicolumn{1}{|c|}{ Errors } & \multicolumn{1}{c|}{ Correct } \\
\hline 1 & I was very excited & I was very happy \\
\hline 2 & I was given a cat & He gave me a cat as a gift \\
\hline 3 & I named him meowy & I gave the name meowy \\
\hline 4 & Because* often in clean & Because it is often washed clean \\
\hline 5 & When I returned from school & I came back from school \\
\hline 6 & He *waited for me & She always waited for me \\
\hline
\end{tabular}

Table B-6: bagus

\begin{tabular}{|l|l|l|}
\hline No & \multicolumn{1}{|c|}{ Errors } & \multicolumn{1}{c|}{ Correct } \\
\hline 1 & She is a cat & It is a cat \\
\hline 2 & Her white hair* & Her hair is white \\
\hline 3 & He often *cleaned & It is often washed clean \\
\hline 4 & Or might be a rat & maybe mouse \\
\hline 5 & When returned from school & I came back from school \\
\hline 6 & He was waiting for me & she always waited for me \\
\hline
\end{tabular}

Table B-7: Ihwal Maulita

\begin{tabular}{|l|l|l|}
\hline No & \multicolumn{1}{|c|}{ Errors } & \multicolumn{1}{c|}{ Correct } \\
\hline 1 & He give my a cat & He gave me a cat \\
\hline 2 & It is cat a cute & It is a cute cat \\
\hline 3 & $\begin{array}{l}\text { I very happy when my uncle } \\
\text { give my cat }\end{array}$ & He gave me a cat as a gift \\
\hline 4 & I always clean my cat & It is often washed clean \\
\hline 5 & Meowy like eat fish & Meowy likes fish \\
\hline
\end{tabular}

Table B-8: Dhea Arischa mustika

\begin{tabular}{|l|l|l|}
\hline No & \multicolumn{1}{|c|}{ Errors } & \multicolumn{1}{c|}{ Correct } \\
\hline 1 & So cute & It is a cute cat \\
\hline 2 & $\begin{array}{l}\text { I *very happy when my uncle } \\
\text { give my cat }\end{array}$ & He gave me a cat as a gift \\
\hline 3 & I always clean my cat & It is often washed clean \\
\hline 4 & Meowy like eat fish & Meowy likes a piece of fish \\
\hline
\end{tabular}


Table B-9: Muhammad rahul akbar

\begin{tabular}{|l|l|l|}
\hline No & \multicolumn{1}{|c|}{ Errors } & \multicolumn{1}{c|}{ Correct } \\
\hline 1 & She's a cute cat & It is a cute cat \\
\hline 2 & I $^{* *}$ name meowy & I gave the name meowy \\
\hline 3 & $\begin{array}{l}\text { She is very cute, her }{ }^{*} \text { white } \\
\text { hair }\end{array}$ & Very funny, her hair is white \\
\hline 4 & He often *cleaned & It is often washed clean \\
\hline 5 & Might be a rat & Maybe a mouse \\
\hline 6 & When I returned from school & When I came back from school \\
\hline
\end{tabular}

Table B-10: Thaharah maulida

\begin{tabular}{|l|l|l|}
\hline No & \multicolumn{1}{|c|}{ Errors } & \multicolumn{1}{c|}{ Correct } \\
\hline 1 & He give my a cat & He gave me a cat \\
\hline 2 & It is cat a cute & It is a cute cat \\
\hline 3 & My ${ }^{* *}$ name meowy & I gave the name meowy \\
\hline 4 & $* *$ White hair & Her hair is white \\
\hline
\end{tabular}

Table 11. Summary of the analysis of frequent subject and verb agreement errors made by the student

\begin{tabular}{|l|c|c|c|}
\hline NAME & OMISSION & MISINFORMATION & MISORDERING \\
\hline Sri Mulia & 3 & 1 & 1 \\
\hline Dio May Asyra & 2 & 5 & 2 \\
\hline Mirna & & 3 & 2 \\
\hline Pradhika Pramudya & & 4 & \\
\hline Intan Syafira & 1 & 5 & 1 \\
\hline Bagus & & 5 & 1 \\
\hline Ihwal Maulita & & 3 & 1 \\
\hline Dhea Arischa mustika & & 3 & 1 \\
\hline Muhammad Rahul Akbar & & 5 & 2 \\
\hline Thaharah Maulida & & 2 & 11 \\
\hline TOTAL & 6 & 36 & \\
\hline
\end{tabular}

Based on the above data, the students in Langsa still faced difficulties in subject-verb agreement. Two reasons were assumed that students still made some mistakes in SVA such as; the students thought that subject-verb agreement material was difficult. As a result, it was not surprising if they did many errors in the aspects of subject-verb agreement. Another reason was because they did not know exactly about the subject-verb agreement rules. They did not know well how to construct correct sentences.

\section{Conclusion}

Based on the analysis of the data and the description in the previous section, it can be concluded that the students in Langsa still had many difficulties in subject-verb agreement. The students had not mastered the use of recount text writing, which can be seen from the number of errors made. They did not know exactly about the subject-verb agreement rules. Although they have been taught about it before, they are still confused which one is used 
Error Analysis of Subject-Verb Agreement Made by Students in Meurandeh Langsa, Rasyid Gunawan, Reni Lestari, Putri Mulyani

when making grammatical sentences. The students are still confused in making an agreement between the subject and the verb. It could happen because in Indonesian language there is no agreement between the subject and the verb. The researcher would like to give some suggestions to students. For the students, they should do more exercises in learning subject-verb agreement and be active to ask the teacher or friends when getting difficulties in learning subject-verb agreement.

The result of this research also found three types of errors experienced by the students namely misinformation, omission and addition. The inter-lingual transfer, intra-lingual transfer, and misleading inputs have caused those errors. In order to overcome the problems, the teacher needs to employ breakthrough strategy/ approach in teaching the students. The activities must enable the students to improve their awareness of subject-verb agreement to write paragraphs in the present tense. It is hoped that by doing this, the students can accelerate their writing so that their English will function well.

\section{References}

Brown, H. D. (2000). Principles of Language Learning and Teaching (4th Ed). New York: Longman.

Dulay, H., Burt. M. \& Krashen S. (1982). Language Two. Oxford. UK: Oxford University Press. Eastwood, John. (1994). Oxford Guide to English. New York: Oxford University Press.

Ellis, R. (1995). Understanding Second Language Acquisition. Oxford: Oxford University Press.

Ellis, R., \& Barkhuizen, G. (2005). Analysing Learner Language. Oxford: Oxford University Press

Greenbaum, Sidney and Gerald Nelson. (2002). An Introduction to English Grammar (2nd ed). Longman: Pearson Education Limited.

Harmer, Jeremy. (2007). The Practice of English Language Teaching. London: Longman.

Huddleston, Rodney and Geoffrey K. Pullum. (2005). A Students Introduction to English Grammar. Cambridge: Cambridge University Press.

Leech, Geoffrey. (2006). A Glossary of English Grammar. Edinburgh: Edinburgh University Press.

Mas'ud, Fuad. (1996). Essentials of English Grammar a Practical Guide (2nd ed). Yogyakarta: BPFE.

Nayan, S. (2009). A Study of Subject Verb Agreement: From Novice Writer to Expert Writer. International Education Studies, 2(30, 190-194.

Spaarks, P. S. (2006). Commonsense Grammar and Style: English For Professionals. Boulder, Co. Westview Publishing Inc.

Sunardi, Hasyim. (2002). Error analysis in the teaching English. KATA: A Biannual Publication on the Study of Language and Literature, 4(1), 42-50. 